
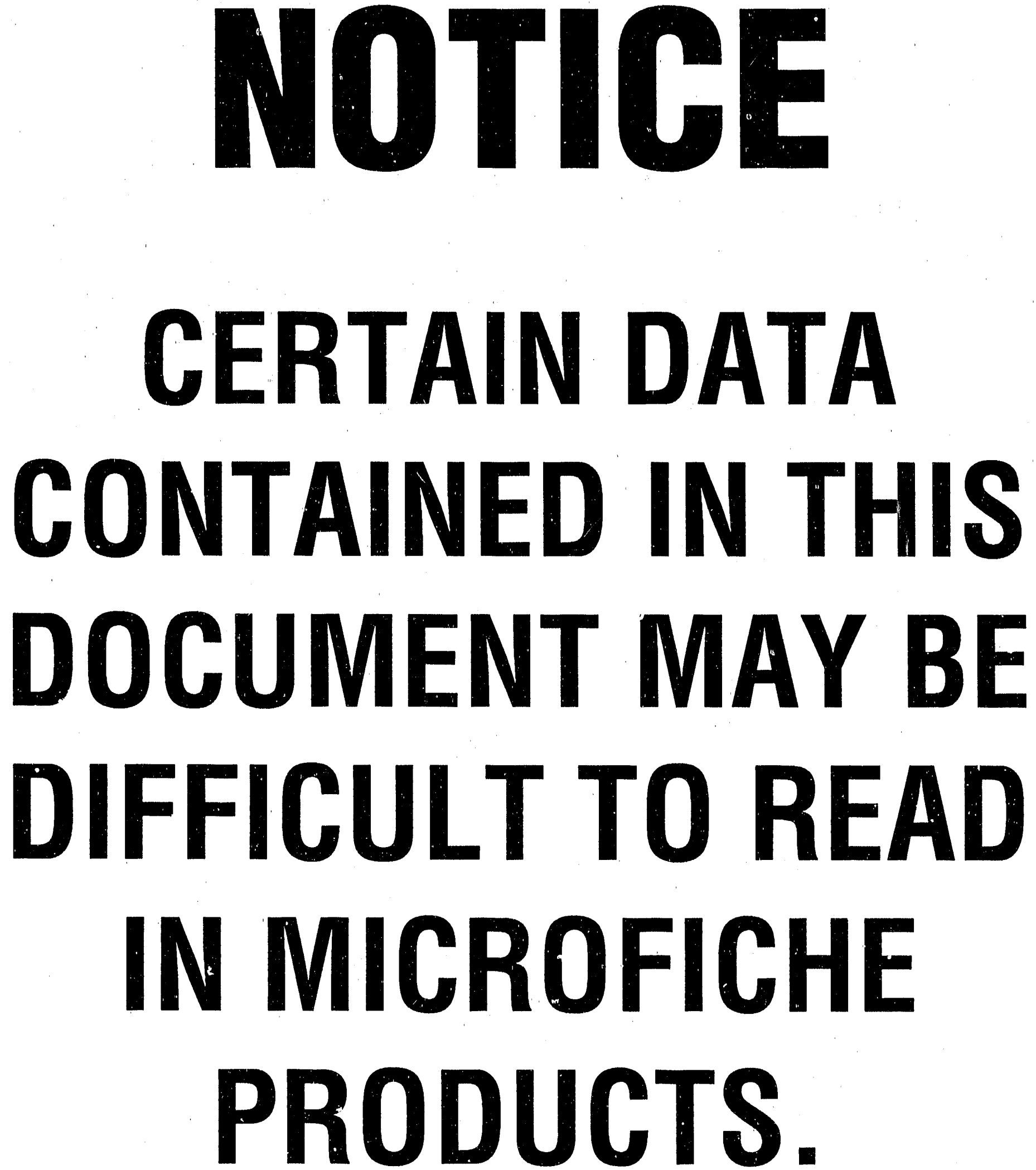
FILE $1+w^{\prime}-120.56-4$

Route LISt

2. Mfidthich 2909

3.

4.

5.
DATE January $\mathrm{H}_{4}, 1949$

SUBJECT P DIvision Honthly Roport

December 1948

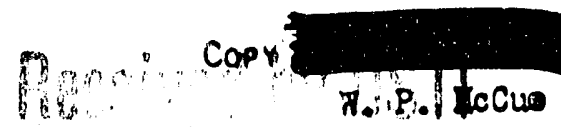

BEFORE READIIS THIS DOCINFNT. II SAN AHIO OATE BELOW:

\begin{tabular}{|c|c|c|}
\hline To & P110 & thotom, \\
\hline FROM & E. P. Lo0 & " \\
\hline
\end{tabular}

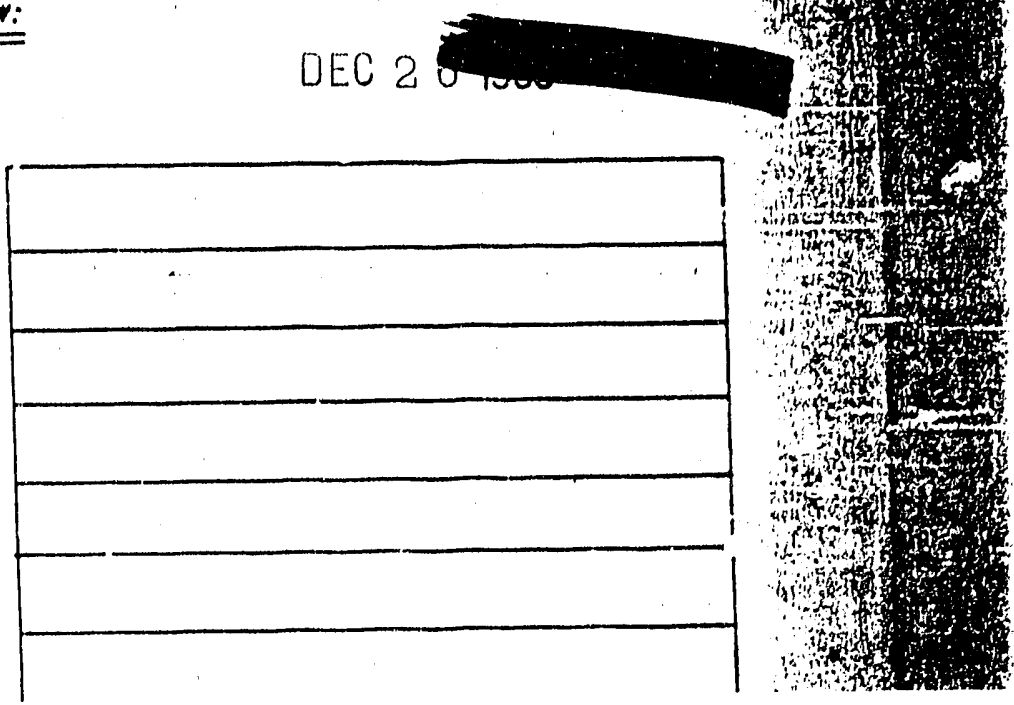

DISCLAIMER

This report was prepared as ant account of work sponsored by an agency of the United States Neither the United States Government nor any agency thereof nor any of their mployees, makes any warranty, express or implied, or assumes any legal liability or responsibility for the accuracy, completeness, or usefulness of any information, apparatus, product, or bility for the accuracy, completenes, or use would not infringe privately owned rights. Referprocess disclosed, or represents that its use would nocess, or service by trade name, trademark, ence herein to any specific commercial product, process, or se imply its endorsement, recommanufacturer, or otherwise does not necessarily constitute or imply its endorem. The views mendation, or favoring by the United States Government or any agency thereof. The views and opinions of authors expressed herein do no United States Government or any agency thereof.
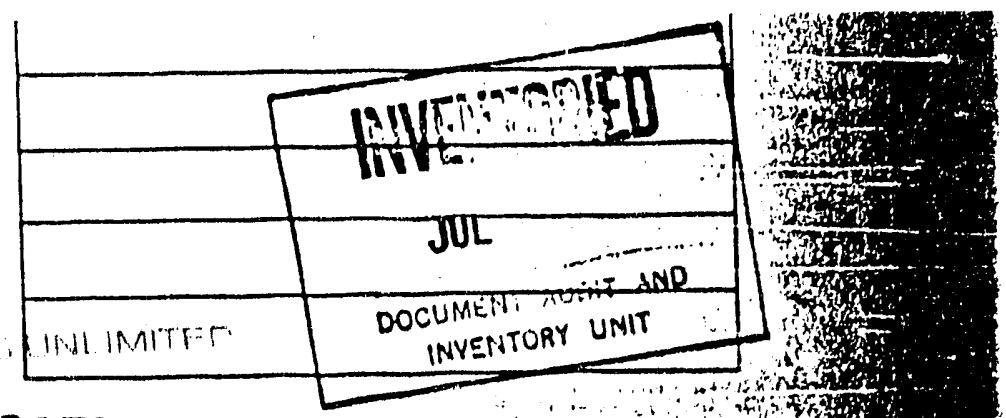

\section{DECLSSTEE}




\section{DEDLASSSFED}

Classitication Cancelled (Change to

Esclesifues

$4 w-12086-4$

By Authority of. $R \leq O-L G-4$

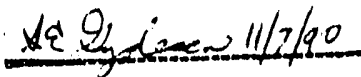

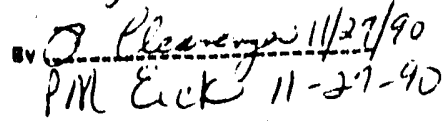

P DIVISION

DECEMBER, 1948

I. GQJERAL

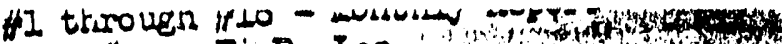

417 - 8i: P. I00

fis - Di: 0. Lieban

417 - P. E. Lorro

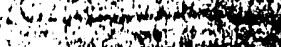

Q120 - H: P. LeCus

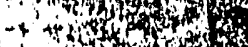

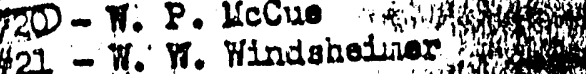

\$22 - A. B; Grantinger int

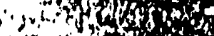

124 - 700 P19

1948

January 14,1949

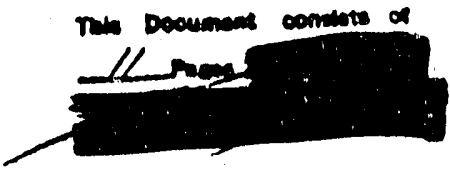

A1I p1les operated at $275 \mathrm{~W}$. W. throughout the month except for the outages listed under Ares activities in this report.

An unscheduled power outage occurred in the 300 Area on Leceriber 2. Tilo outage was a result of overloaded transmission lines and lastod from 4:45 p.m. until 8:45 p.r. No difflcult1os wero encountered except for the lost operating time.

A total of 103 tons of Ifetal was discharged from the p1los during the month.

Operating schedules in the 300 Area were .educed from a oix-day week to a Ilve-day week on Decemoor 20 bocause of the favorable status of the inventory of canned slugs. All processes are now workdng orie shift a day excopt Canning and Machining which work two shtets a day.

II. OTGANIZATIOH AND PERSONIEL

Number of Employees on Payroll - December
Beginning of Morith: 372
End of Month:
Net Increase:

Seven operators were hired and one terminated voluntarily. Twentyfour operators were trangferred to the 100 Areas for tratining in anticipation of the startup of $H$ pile. Three operators were transferred to the $S$ DIvision, and one was removed froin the payroll due to 1liness. Seves, operators from the 100 Area group were assigned to the construction liaison group to assist in following construction checking at the 100-DR pile, offactive necember 20.

Tha following changes in monthly personsel took place during th. month:

R. :\%. Hooper was promoted to Shift Supervisor effectivo

Decenber 2 and assignod to 100-F Area.

G. Eurikir, Shift Supervisor in 300 Area, was transferred to 1CO-F Area on Docember 8.

R. G. Swlft, Shift Supervisor in the 300 Area, was transferred to 10J-F Area on December 13.

DIETRIEUTION OF THO DOUUWEAT RO UNLIMITED

Due to film deterioration, portions of this document may be illegihle. 
P Diviaton

III. AREA ACTIVITIES

PIIE SUMR:ARY

$\begin{array}{ccc}\text { PIIE B } & \text { PIIE D } & \text { PIIE P } \\ 92.3 & 86.5 & 89.8 \\ 91.8 & 84.3 & 87.4 \\ 275 & 275 & 275 \\ 4.3 & 4.8 & 4.8 \\ 47.4 & 47.5 & 49.6\end{array}$
TImo Operated (\%)
Operating Efflciency (
* Power Lovel (M.ii.)
HInlet ïater Temperature $\left({ }^{\circ} \mathrm{C}\right)$
*outlet Hater Temperature (Madimim
${ }^{\circ} \mathrm{C}, 10$ tubes, 0.240" zone)
Number of Scrams
Numbar of Purges
Helium Consumption (cu. ft.)
Metal Discharged (tons)
* Inhours Gained (this month)
*Inhours Poisoned
*Inhours in Rods

$\begin{array}{ccc}0 & 1 & 1 \\ 2 & 1 & 2 \\ 56,675 & 67,704 & 75,666 \\ 36.12 & 26.35 & 40.55 \\ 4 & (-) 2 & (-)^{7} \\ 280 & 443 & 402 \\ 62 & 60 & 38\end{array}$

* Month end figures.

* Does not include increased react_vity due to $\mathrm{CO}_{2}$ in gas system.

\section{PILE BUILDING}

Outage Breaktown

Sctieduled

Length of

Date of Outage Metal Discharged Maintenance Unscheduled Qutage (Hourg)

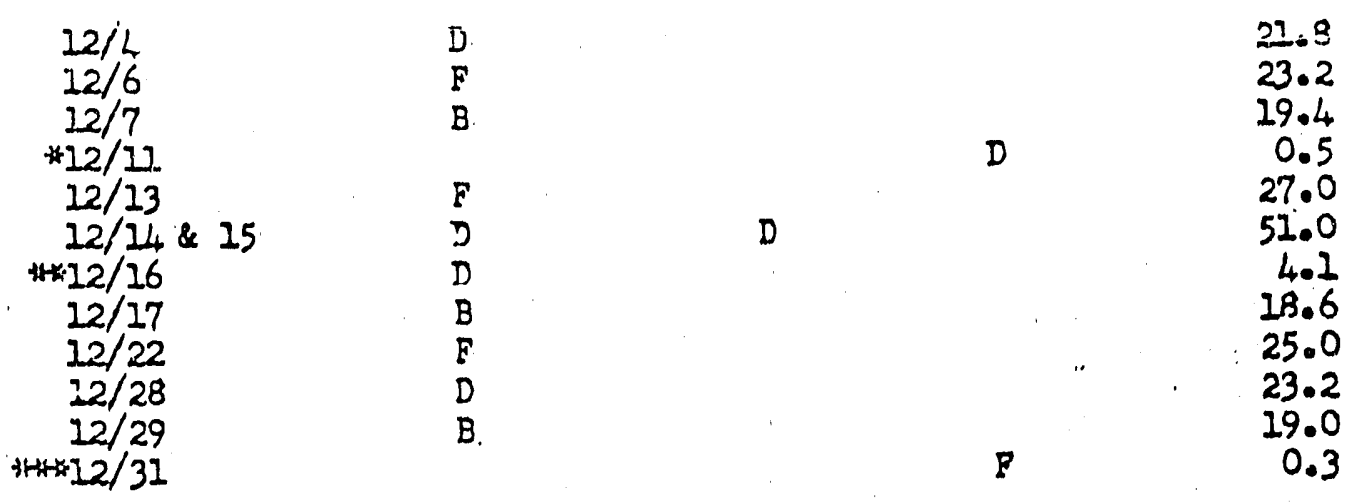

* Sc:am caused by faulty electrical connection in \#l Beckman. ** Shut dorm to discharge temporary poison.

* Scram caused by momentary surge of th Bockmari.

Operating Experience

Production tests having operational signiflcance are reported below:

105-114-P (Van Storie Flange Corrosion Tests)

Magnesium alloy slugs were positloned at the front

Van Stone flange in $91 x$ tubes in the $F$ pilo in

order to eveluate their effect on Van Stone flaige

corrosion. All six Van Stone Planges wero in good

condition. 
105-168-P (Replacement of P1lo Halium Atrosphere Wh $\mathrm{CO}_{2}$ ) All three plles are norl operating with $\mathrm{CO}_{2}$ in the hollum atmosphere. Changes which were mace durling the month and month end conditions are listed below:

100-B: Additions of $\mathrm{CO}_{2}$ were begun December 20 and increased in increments of 36 at 24hour Intervals. Checks of opsrating data and urit motion indlcators rovealed no abnorma? conditions. The concentration of $\mathrm{CO}_{2}$ at month ond was 10\%. This concentration will be increased during January, 1949, when additional unit motion indicators have been Installed.

100-D: The concentrattin of $\mathrm{CO}_{2}$ was held at $40 \%$ during the entire month. No charges in operating conditions were noted.

1CO-P: Additions of $\mathrm{CO}_{2}$ visre begun on December 3 and the concentrations wers increased in $3 \%$ increments at 24-hour intervals durins equilibrium conditions until December 18 when $25 \%$ concentration was reached. This concentration will bo held for complete evaiuation of tine results of this change. No unexpected operating conditions were observed during this chanpe.

\section{5-194-P (Unannealed Alpha kolled Slugs)}

Eight tubes, each containing sixty-four four-inch unannealed alpha rolled pleces, were discharged without incident on Jecember. 22.

Exambation of the 4-Inch metal pieces discharged from Tute No. 0569-B, which contained a rupturesd piece (see P Division Lonthly Report for November), revealed a piece with the cap displaced. A protrusion was noted on the exposed end of the tal slug. The force excerted on the cap by the metal apparentily caused a mupture of the can wall at the interface between the metal and the cap. The cap weld ras pound to bo Intact. Iotalls of this examination will be covered in a special report. A borescopic exanisation of this tube revealed no damage and it $F: y$ roloaded with regular metal.

All three piles experfenced unusual pressure drop acceleration during the month. These increases are corsidered abnomal for this season of the year and 1ivestigations of this problem are under way.

Considorablo difficulty Was experienced with tho discharging of alpharollod, lead-dipped metal during the month at the $D$ and $F$ piles. A tutal of 66 tubes contalning this typo of metal requirod extensive ofleing beforo thoy could be discharged, and four of the tubes at $P$ Area required ono hour's saturation with oll beforo thcy could be discharged. The metal in theso tubes had an average concantration of $225 \mathrm{M.} \%$./ton; in view of these difficulties a decision has been made to abandon any efforts to Incroase, beyond this point, the copcentration of the resaining 62.5 tons of alpha-rolled, leadidipped fital nat in the piles.
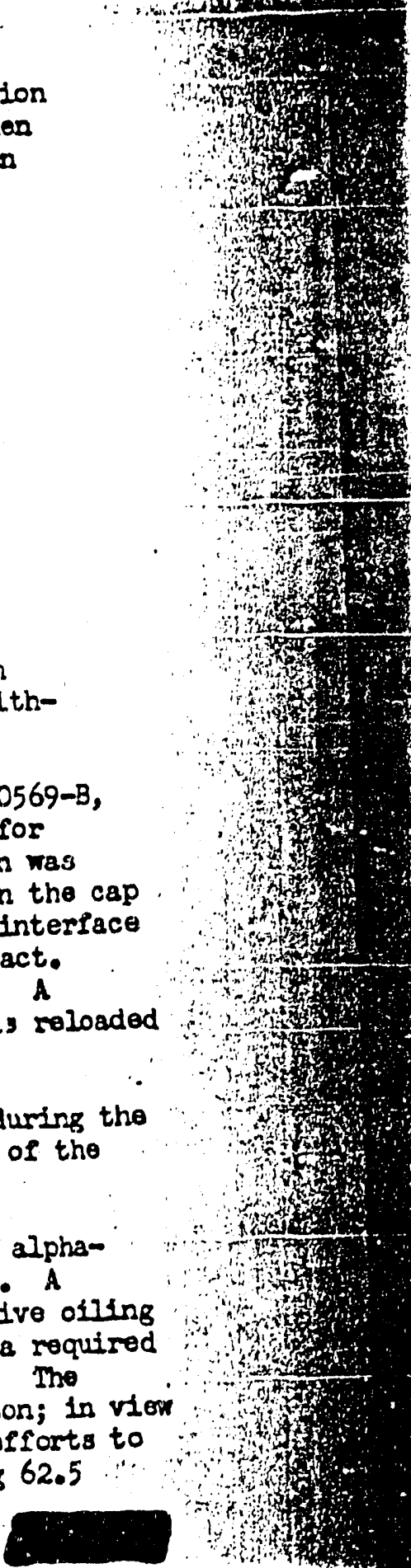


\section{P Division}

A stuck slug was encountered at D Area on December 4 in Tubo No. 1788-D, which contained alpha-rolled, lead-dipped metal. The slus was successfully discharged using the usual stuck slug procedures and the hydraulte oquipment. The tube wes replaced and recharged on the same day.

\section{Yechanical Exportence}

All horizontal and rertical safoty rods wore in satisfactory operating condition at month end with the exception of three vertical nafety rods, No. 23 at B Area and Nos. 27 and 36 at D Area. Vertical Safety Rod No. 23 at $B$ Area was sticking at month ond and will be corrected during the firgt outage in January.

No. 27 Vertical Rod at D Area was dismantled during the December 15 outago and a new $2 i_{4}^{\prime \prime}$ (DR) type stadnless steel rod and guide were installed. The rod fait.ed to go in when tested and an at tempt to install an eccentric rod guide was abandoned when it was found that the interior of the guide was rough. The old rod and guide were replaced on December 28 but remained inoperable at month end. No. 36 vertical rod at $D$ Area became tangled during the atartup of December 28 and was secured in the out position until the first outage in January.

Other work, of an unusual nature, on safoty rods during the month Included:

1) During routine maintenance work on Rod No. 37 at B Area, the saction next to the tip was found to be split and was replaced. ilork was continued jurins the month on the realignment of No. 4 horizontal rod at B Area and at month end the gallins corlition noted in last month's report had been corrected.

2) The Instailation of the new $2 \frac{1}{4} "$ (DR) type stainless steel rods and guides in No. 15 position at D Aroa and in No. 11 position at $P$ Area was made. These installations mere made to ovaluate the performanco of this typo rod.

3) No. 6 Horizontal Rod at F Area stuck during pre-startup tests on Decombir 6. Reailignment of the outor rod guides and removal of rough spots on the side of the rod resulted in satisfactory oforation. Examination of No. 7 Horlzontal Rod at $P$ Area rovealed several gouged spots on top of the rod. The rough spots were ramoved but the rod stili tands to bind at the extreme "In" position.

4) A vertical aligment of all rod guldos at D Area was comploted during the month.

Two process tubes rore replaced durting the month as follows:

Tube No. 1467-D was replaced on Decembor 14 after having been discharged ritin difficulty on Novembor 16.

Tube No. 1788-D was replaced on Decomber 4 after difficulty had been experiencod in discharging it.

$$
\text { DECLASSIFIED }
$$


During the course of the yearly Van Stone Ilenge Inspections at D Area, a aplit front flange was found on Tube No. 4561-D. Since there was insurflcient gunbarral clearance avallable to allow turning a new Van Stone Plange, it was nocessary to discharge the partially exposed metal and make preparations to Install a new tube. The now tube will bo installed during the Nirst outage in January.

Adiltional unit motion indicating equipment was Installod during Docember at $D$ and $F$ sreas in order to evaluate more accurately the effects of $\mathrm{CO}_{2}$ addition to the pile atmosphero.

A part of the concrete wall which separates the $207-D$ and 107-DR flumes at uhe 1904-D Building was removed during the Decemoer 14 shutdown in order that the water irom the 107-DR Buliding could be diverted to the river vis the 1904-D river offluent Lines.

During the annual overhall and inspection of the 100 $\rightarrow$ Ares 30-ton thiting crane, the drum was reground and new cables wero installed. In accordance with Engineering Recommendation No. 100, a new stainless steel alloy brake shaft was installed; similar installations will be mnde at the other 100 Areas in the future.

Calcium hypochlorite was added to the water heel in the south side of the 107-D basin in a continuation of the algae control program. Resulis appear to be satisfactory.

P1la Develonnent

In articulated perforated aluninum durew train used for soating the charge in tubes containing no front dummies has been developed and tested sat1siactorily. Iinkir.s theso duninies togethor in this manner provides a timo-saving method of withdrairing the dumies from a tube without the usa of a long rotrieving rod.

As tho result of a study of powor lovol cutbacks rosulting from high exdt wator temporatures following start-up, the stiundard rod withdrawal order at 100-B Pilo was rovised, Interchanging No. 8 and No. 5 rods. The revisod withdrawal ordor permitted normal start-ups without cutback on tho outages of December 7 and 29. The rovised order has now been estabIished as standard at 100-B.

A concrote pad used during construction of tho DR Pile has been modiffed and fancod in for uso 38 a cask storago and handling aroa.

In an effort to decreaso the timo required for chargo-digcharge operation and in order to more easili remove piecos whicin are difficult to dischargo, tho following staps were taken cluring tho month:

1) The ais systcm pressure mas increased from 80 p.s.1. to 100 p.s.1. to enablo tho rogular charging machine to movo tho "roluctant" piocos. It is estimated that this chango reduced the timo requirod for discharging a tubo by twanty-plve percant. 
P Division

a

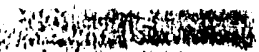

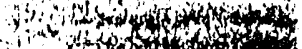
4

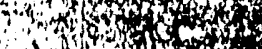
(n)

2) The fabrication of expanding rubber plugs, which may be inserted ins ido the and of a tube theroby shutting off the water supply and allowing the tube to be f1lled quickly with the ofl silution and left until later for discharge, has roduced the twoo consumod in dsecharging "roluctant" tubes.

3) The fabrication of a fourteen-foot sesting pole to seat charizes a. Ver the front dumpr chargo has been removed has allowed inese front dumbes to be retrieved during a normally idlo timo for the front face crews; it is estimated that appradmately one hour of elevator time is saved during a thirteen ton discharge as a rosult of using this piece of oquipment.

\section{GAS PPOCESSING BUITOING}

The dismanting and transfer to Construction of equipment in No. 2 purirication room and No. 2 purge blower room at B Area was campleted during the month.

\section{SPECIAL HAZARDS}

During the month, the 107-B pump room and the 105-B apparatus room danger zones were reduced in size as a part of a program aimed at reducing costa by elininating unnecessary S. W. P. handling.

The contaminated car which was recelved in November containing a return shiprent of "B" casks (see Novemior report) was rehabilitated by replacing the floor boards and side vralls to a height of three foet. The car has been released for service.

Readings on the top far neoprene seal at F Area increased during the month to $1350 \mathrm{mr} / \mathrm{hr}$ average as compared to $480 \mathrm{mr} / \mathrm{hr}$ roported durling November. This reading ircluded a reading of 54 mren/hr of fast neutrons.

After the installation of the shorter rod guide in No. 27 thimble ai F Area, readings of $173 \mathrm{mran} / \mathrm{hr}$ of fast neutrons were experiunced at the busper plate. This condition resulted in a fast noutron reading of 13.5 mere/hr at the vertical saloty rod rail. The reading at the rail is approximatels ten times greater than normal. Flans are now boing developed to install additional shielding above the bumer plate.

\section{AREA - METAL FABRTCATIOIN}

Production Stet1stics

Production for the month of Decamber was as follows:

Billets Produced

Rods liachined

Accoptablo Pleces Cannod
36 Tons

190 Tons

UI Tons

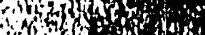

1640

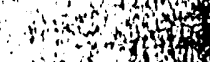

it
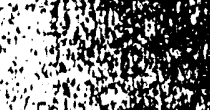

trobstom

boris

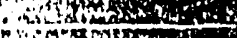

-

- 9xom

nom

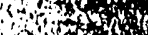

oribow 3 1375s

stom

34

4 x

wh

ing

$\rightarrow$ moth

,

is

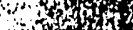

1)

$n$

7

sind

$2 x^{3}$

nownts

stres

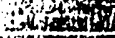

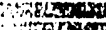

it

$+4$

1,34

2in

trts

ting

14t 24

sing

$x^{2}$

14y

196

titix

trom

15t

in

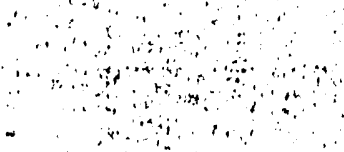




\section{rubantan \\ DECLASSIEIED}

P Division

Melt Plant

The caoting jlelds wore as followss

a

Afon

B1I Iot

Solsd Material

November $\because$ December

66.7

84.3

61.3

80.2

and

Considerable difliculty was experlenced durlng the month" whth rough surfaces on billets, thus causing a reduction in the yield. It appears the rough surface condition results from the uneven application of the Iirconite mold wash on the inner surface of the mold, accompanted by insuericient drying befors use. The use of the Zirconite wash will be continued on a controlled basis for another month, however, In an affort to realize the 1mproved mold usage reported by other sites to moult from the use of a mold rash; in this connection, the temperature of the mold proheat oven wlll be incressed to the maxim possible in order to minimize the effects of inadequate drysing.

One hundred crucibles fabricated from CS-312 graphite have been roceived. Twerty-five crucibles of each of the follonding four types were included In this order: Standard dimensions, standard dimensions with taparad Inner sidewall, standard dimensions except for tbick wall, and thicil-wall with tapered inner sidewall. The evaluation of these crucibles was atarted on December 22.

Several billets were processed during the month w.th flat and ohemosred ends instuad of the conventional 068 and. The rods rolled from these billets will be checked to determine if the quality of rod ands is improved.

Authorization to roduce the sampling of casting heats from $100 \%$ to 108 of all beats was recaived on Deccomber 23. 'Tnis change is outilined in the revised "Operating Process for Uranium Remolting and Casting", Documant No. $457-11745$.

Machintns

Machting yiulas wert as follows:

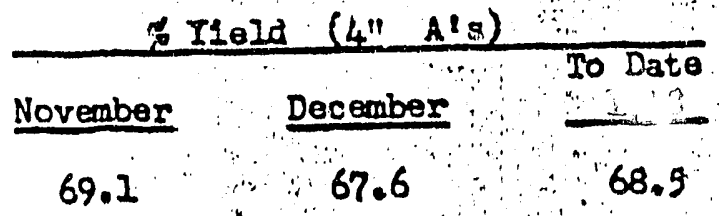

Chin Reconero

Tho Chip Racovery gleld wers as follows:

\& Yield

Novembor
97


P Diviaion

in.

The ent1re Chlp Recovary Process wes operated 14 olght-nour ahtets, with tho press benting cperated an additional 19 oight-hour shifto. A total :of 66,394 pounds of 208 was produced.

The Chip Recovery operation was shut dom on November 24 because of excessive vibration in the centrifuge: Repatrs wore comploted and operathan resumed on December 2. On December 251 was nocessary to ahut down. agaln when the shaft assembly was broken loose from the housing of tho

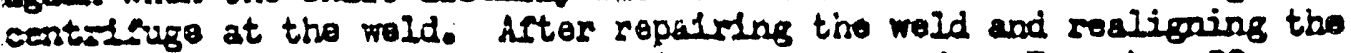
shaft and basket assembly, operation was resumed on December 22.

The material burned in tho adde burner was as follows:

\begin{tabular}{ccc}
\multicolumn{3}{c}{ We1ght Out - Lbs: } \\
\hline November & December & $\frac{1948}{10 \text { Date }}$ \\
20,309 & 14,458 & 129,981
\end{tabular}

Canning Operation

The canning gieid was as follows:

\begin{tabular}{|c|c|c|}
\hline Hov ember & Decemher & $\begin{array}{c}\text { To Dazo } \\
1948\end{array}$ \\
\hline 38.6 & 87.1 & 88.5 \\
\hline
\end{tabular}

Canning rejects, by cause, wero:

\begin{tabular}{|c|c|c|}
\hline November & December & $\begin{array}{c}\text { To Date } \\
.1948\end{array}$ \\
\hline $\begin{array}{l}2.8 \\
2.7 \\
0.5 \\
1.9 \\
0.9 \\
2.6 \\
\end{array}$ & $\begin{array}{l}3.5 \\
3.0 \\
0.7 \\
2.4 \\
0.9 \\
2.4\end{array}$ & $\begin{array}{l}4.1 \\
1.8 \\
0.9 \\
1.4 \\
1.5 \\
1.8 \\
\end{array}$ \\
\hline 21.4 & 12.9 & 22.5 \\
\hline
\end{tabular}

The cunnting ylold ves 1.5\% 1883 than that for November. The incroase in non-seats, marred surpaco, and frost test rejects was tho major cause for the lower trend in ,iseid. The quality control program started last moniti io reduce non-seating and bad weid rejects was extended to cover marred surface and frost test rojocts on December $150^{\circ}$ Some reduction in marred surface rejects was rajlized during the lator part of the month. 
Frost test rofects wore reduced approciably after December 21 when tho use of atandard 4n caps was resumed. A large percentage of the lrost test rojocts prior to that dato was caused by tho increased torquo applied to the alternate thick cap durlas lacing, which broke tite bond betwean the can and the slus at the base of the cap.

Work was continued on Production Test No. 313-107-W, (Supplewent A), ("Effect of Canning Conditions on SIug Ylold and Quality"). The canning of 5842 sluga, machined to a diameter of $1.352^{n} \pm: 82^{n}$ and iength of $4.040 " \pm .010 "$, was completed on December 1 . In addition tro other lots of 100 slugs each, machined to a diameter of $1.350 " \pm .00{ }^{n}$ and a length of $4.045^{\prime \prime} \pm .010 "$, were canned with an equal number or control. slugs having stancard "A" dimensions. Non-seating rojocts were olgniflcantiy lower for the smaller dininster slugs and no Alsi pecetration of the can wall to within less than .010n of the surface ras found. Control places showed as hifich as $8.3 \%$ penetration to within lass than .010n of the can surface.

Trenty-four slugs were dipped in the bronze and tin baths and quick quencined in water. Later thay were rehested in the $t$ in bath and canned. Thts was a part of the preliminary work on Production Test No. 313-108-x, ("Effect of muiuk nuenching from the Beta Phese on the Behavior of Urantum Slugi" 1 ). The purpose of this test is to propare canned slugs for pile testing that are free or almost free of columar grains, and with a grain size that is 5 to 10 times smaller than that of standard triple-dipped slugs.

The following special canning was done during the month:

Request No.

S. R. 80

S. R. $80-1$

S. R. 85

S. R. 86
Contents

Lorcuric Oadde

Lorcuric Cxide

Sol.antum

Thallium Nitrate

Numbar of Ploces

In addition, 30 roceptacle slues, 51 papooso slugs, and 6330 poisan slugs were cannsd.

Racovery Oporation

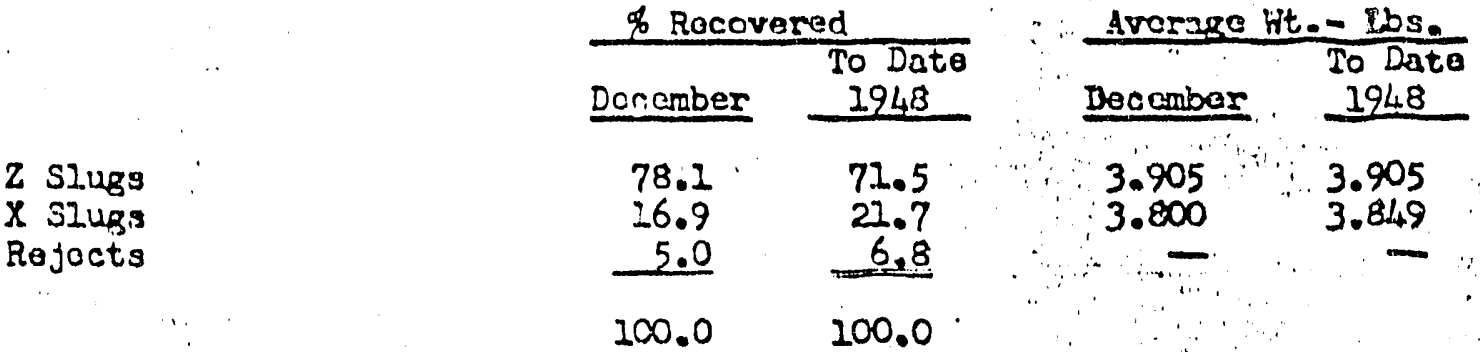

\section{Recovari Oporation}

$100.0 \quad 100.0$ 


\title{
P. Divisiun
}

\section{Ingpect1cy and Tosting}

Autoclatre refects io:e as follows:
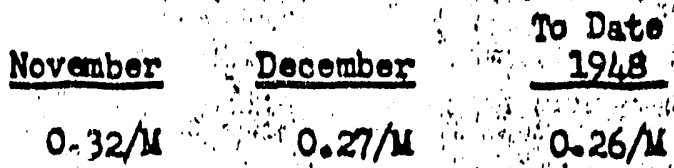

\begin{abstract}
A total of twentymone autoclave fatlures ocourred in December. A Iarge percentage of the fiatlures were in the uppor one-thtrd of the pleces and resulted from pinhol.ss in the can wall and around the rold bead.
\end{abstract}

The "As Recolved" quality of cans, caps, and sloeves was as followsi

\begin{tabular}{ccc}
\multicolumn{2}{c}{ of Usablo-(4") } & $\begin{array}{c}\text { To Dato } \\
\text { November : December }\end{array}$ \\
\hline & 948 \\
93.6 & 95.2 & 92.5 \\
96.5 & 96.8 & 96.6 \\
51.5 & 98.4 & 86.0
\end{tabular}

Aluminum Cans

Aluminum Caps

Stoel Sleeries

A supply of standard $4^{\prime \prime}$ aluminum caps was received and the use of alternate

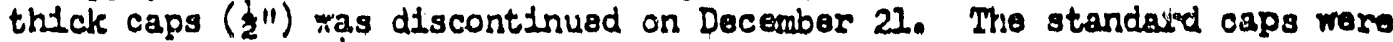

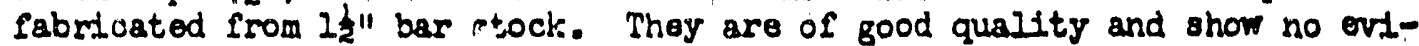
dence of the folds or crack in their peripheries which caused provious difflculty in welding.

The Inspection of 4.95 aluminum cans recolved from the Aluminum Company of Amexica, whtch wers impact extruded from blanks out from sheot aluminum Instead of being cut srom bar stock, was coimploted on December 2. A total of 440.1 or $88.9 \%$ of these cans was usable. The breakdown of rejects was as foltows:

$\begin{array}{lr}\text { Marred Surface } & 362 \\ \text { Small Inside Diamoter } & 26 \\ \text { Dents } & 138 \\ \text { Thick Bottoms } & 9 \\ \text { Thin Bottors } & 14\end{array}$

The acceptable cans were later used 1ri canning with satisfactory results. Material Handling

Seventy-eight tons of rods were recelved frorn Vulcan Crucible Steel Campany and 156 tons from Simonds Saw and Steel Company. Elghtymine tons of biliets were shipped to Vulcan Crucible Steel Company and 15 tors of adde

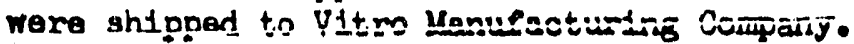

305 Area Test P1le

A total of 138 tests was run on canned slugs, 57 on b1110t eg8, 589 on graphitie bars, and the lollowing on spocial work requests. 

P Dirsion

Fequest Nio.

arts

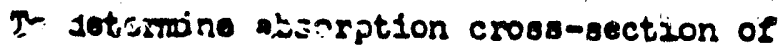
inroe srisises of aluminum ulloyed with

Ho. of Testa magnesium.

45

To deterratile absorption cross-section of AlS1 allo; ci with magnesium.

10

0

46

To deterntine absorption croso-section of Aqua-Daz.

47

To obtatr ratio between noutron flix on the outside of a bare slug and Mlux on inside, for use in theoretical calculations.

20

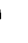

To obtain relative absorptions of a regular poison slug and new typo cadmilum plated spltine for use in 105 piles.

In addition to the above, 16 test, 3 were run in conformance with Produvition Test No. 313-107-1/, Supplement A, ("Effect of Canning Conditions an Slug riold and nuality"l).

\section{Special Hazards}

No unusual conditions developed during the month.

Development

$A$ test was rade to dotermino if a viscostmeter could bo used to indicato "hanges in the viscosity of the AiSI canning baths which might contribute to wi-aeatine rejects. The viscosineter did not havo sufficient sensitivity and indicine ef littis or no change in viscosity over a range of $20^{\circ} \mathrm{C}$ in boith +opeture. nifitional testing 19 plarined if the 1nstrument can be mado more senszilive.

Proltminary chocks were made on several gamma ruded olugs to chock the theory that it might bo possivle to obtain a grain structure similar to alpha rolied slugs aiter beta transformation. Pour roce red gamms ererijed slugs were processed through the bronze and tin at zorral temperacures and on regular arcle, followed by a outck quench in watyr. The graln structure as sbeerved in the regular cracking tost. appuarod to be the same as for alphs rolled slugs; however, laboratory reports indicated the groins were socewhat coarsor.

Prolt-inary desien work hss been sturted on facillties for plekling rods

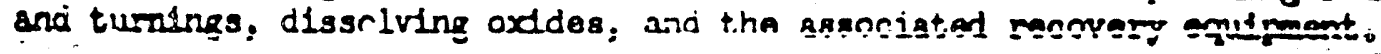



